\title{
Big Society and community: lessons from the 1998- 2011 New Deal for Communities Programme in England
}

\author{
Paul Lawless* \\ Sheffield Hallam University
}

\begin{abstract}
The Coalition government which came to power in the UK in May 2010 has placed considerable stress on the Big Society. Assumptions underpinning this approach to policy and societal change are largely unevidenced. The evaluation of the ten year New Deal for Communities (NDC) Programme launched by the previous Labour government in 1998 has important implications for community-level decision making, a theme central to the Big Society. The NDC experience points to problems in this domain including intra-community strife, lack of engagement, and community representatives being wrong about the scale of, and appropriate policies through which to moderate, local problems.
\end{abstract}

Keywords: Big Society, community, regeneration, evaluation.

\section{A brief introduction to 'the Big Society'}

One theme central to rhetoric surrounding the United Kingdom's (UK) Coalition government emerging out of the May 2010 elections, is the 'Big Society', the building of which is apparently the new Prime Minister's 'great passion' (Cameron, 2010: 1). The underpinning planks to the Big Society revolve around a number of core themes (Barnard, 2010) including a stress on localism, enhancing individual responsibility to address needs, a diminishing role for the state, and increasing accountability. There is probably general political and policy consensus that some of these principles are sensible. The idea of devolving responsibilities where possible to the most appropriate tier of 'governance' might, for example, be generally welcomed across the political spectrum. So too would be an enhanced role for the 'third sector' in delivering public services (Cabinet Office, 2010a). However other aspects of the package, including its role in distracting attention from wider political change implemented by the Coalition government, have been subject to critical comment (Alcock, 2010; Coote, 2010; Kisby, 2010). 
p. 56. Big Society and Community: Lessons from the 1998-2011 New Deal for Communities Programme in England

Whatever the merits of these debates, one marked weakness in the position of those advocating the Big Society is the lack of a supporting evidence base. In Cameron's scene-setting 2010 speech, and in other documentation (Cabinet Office, 2010b; Conservative Party, 2010), grounded evidence from which to legitimate this approach is limited at best. Those driving this agenda appear to base their convictions, not on a balanced reflection of existing evidence, but rather on fashionable, populist polemic (Blond, 2010), informing a 'common-sense' perspective on society. Ironically where efforts have been made by Conservative commentators to inform the Big Society, key messages can be ignored. A review of the apparent success of regeneration schemes in Birmingham identifies the critical role played by long-term public funding (Wind-Cowie, 2010), a lesson conveniently forgotten by those formulating the Big Society. However, although by no means a perfect simulacrum of the Big Society, there is an evidence base against which to assess the plausibility of some assumptions central to the Big Society: the 1998 to 2010 New Deal for Communities (NDC) Programme. This paper outlines the nature of that Programme, using findings from its evaluation to explore one theme in particular where there is strong complementarity between the Big Society and the NDC narrative.

\section{New Deal for Communities: an overview of the Programme and its evaluation}

The NDC Programme, launched in 1998, was designed to 'help turn around the poorest neighbourhoods' (DETR, 1998: 1), thus reducing 'the gaps between some of the poorest neighbourhoods and the rest of the country' (DETR, 2001: 2). 39 NDC Partnerships were established across England to attack problems within relatively small deprived areas each consisting on average of 9,800 people. NDC Programmewide funding was to be about $£ 2$ billion, approximately $£ 50$ million to each of these 39 locations. In order to assist in transforming these areas, each NDC was expected to achieve positive change in relation to three place-based outcomes: crime, the local community, and housing and the physical environment, and also three people-based outcomes: health, education and worklessness. NDC Partnership Boards, consisting of local residents and representatives from key delivery agencies, were to provide overall direction working with agencies such as the police and local authorities. In addition the Programme was to ensure the community was at the heart of the initiative.

The NDC Programme reflects that long history of English urban regeneration initiatives. From the mid 1960s onwards, both Conservative and Labour governments instigated initiatives to improve conditions evident in English cities ${ }^{1}$. The articulation of, and implications arising from, this strand of urban policy are well documented (Kintrea, 2007; Shaw and Robinson, 2010), and parallel similar developments in the United States (Oakley and Tsao, 2006), and Europe (van Gent, Musterd and Ostendorf, 2009). A number of principles characterised English regeneration programmes. Central, rather than local, government drove this agenda: identifying programmes and creating national guidelines for their operation. Policy was implemented through Area Based Initiatives (ABIs) wherein limited additional resources were provided to time-limited programmes operating in pre-defined localities. Although falling within this tradition, there were elements to the NDC Programme which nevertheless made it different to many previous ABIs: its ten year time horizon, the allocation of generous budgets to small neighbourhoods, and its emphasis on community engagement.

In 2001, the government's Office of the Deputy Prime Minister (ODPM), later Communities and Local Government (CLG), commissioned an evaluation of the Programme. The first phase of this culminated in the publication of an Interim Report (NRU/ODPM, 2005), and a second which reported in 2010 (for an overview: see CLG, 2010a). The evaluation involved analysis of both quantitative and qualitative evidence 
p. 57. Big Society and Community: Lessons from the 1998-2011 New Deal for Communities Programme in England

from across the 39 areas. Specific data sources and associated publications are referred to in later sections of this paper. But one key data source should be flagged up at the outset because it proved the most important evidence base for assessing change. A household survey of residents aged 16 or over in all 39 NDC areas was carried out on a biennial basis between 2002 and 2008. Sample sizes ranged from 19,574 interviews in 2002 (500 per NDC area), to 15,840 in 2008 (400 per area). In addition, a smaller comparator areas survey was carried out to establish a benchmark of what was happening in other deprived neighbourhoods. This took place, at the same time, in three similarly deprived wards to those accommodating NDCs within the same parent local authorities. To give a sense of the size of this survey, some 2,014 respondents in comparator areas were interviewed in 2002, 3,100 in 2008. Because both surveys involved returning to those interviewed two years previously, it was also possible to create both an NDC, and a comparator, areas panel of residents who had lived in one of these neighbourhoods for that six year period 2002 to 2008 . It therefore becomes possible to explore change both across the 39 NDC, and their comparator, areas, but also for individuals remaining in one of these neighbourhoods through time. The 'net NDC change' over and above that occurring in the comparator areas, represents the best estimate of NDC impact.

Evidence from the NDC evaluation provides what, in the UK context, is probably an unprecedented evidence base through which to assess change as a result of neighbourhood or 'community' level interventions. It therefore provides a useful prism through which to validate assumptions central to the Big Society. But before embarking on that task, one caveat should be made. Although there are themes common to the NDC Programme and Big Society, there are marked disjunctures too. For example, when the NDC Programme was launched in the late 1990s there was little local demand for an $\mathrm{ABI}$ designed on these lines. This was not the "local community' in action, rather central government defining and driving through a 'topdown' initiative, to operate in specific, pre-determined, neighbourhoods. Nevertheless, there remain close similarities between what the NDC Programme attempted to achieve and what drives the Big Society.

\section{Disentangling the community dimension}

To the Deputy Prime Minister, the Big Society represents a 'radical dispersal of power away from Westminster and Whitehall, deep into communities across the country' (Clegg, 2010: 3). In so doing 'government must commit to the active empowering of local communities, not merely cease to disempower them' (CLG, 2010b: 7). To aid this process, the government has introduced a Localism Bill which amongst other provisions, outlines a right to buy provision to allow communities buy threatened assets and neighbourhood plans to give local communities rights to shape the development of their areas. It is worth pointing out here that aspects of this thinking are not new. The then Labour government set out similar arguments in the 2000s, in proposing, say, increasing opportunities for communities to own local assets, to use delegated budgets to fund local projects, and holding authorities to account through Community Calls for Action (Home Office, 2005; CLG, 2006). It will be intriguing to see whether the community dimension central to Big Society proves more resilient than was the case with 1997-2010 Labour government. But however this pans out, there is no doubt that the NDC narrative provides robust evidence with regard to how the community dimension plays out at the local level.

No previous $\mathrm{ABI}$ has ever placed such an emphasis on the community dimension (CLG, 2010e). This strategy was adopted for a number of reasons. It would help reduce social exclusion; provide a clearer steer as to the needs of these areas; 
p. 58. Big Society and Community: Lessons from the 1998-2011 New Deal for Communities Programme in England

enhance the quality of decision making; and improve the chances of sustaining benefits once funding ceased (Dargan, 2009). To achieve these ends, the community dimension to the NDC Programme attracted almost one-fifth of total spend (over 300m $£$ by the end of 2007-08). The NDC experience thus provides a laboratory within which to explore the implementation of, and outcomes associated with, community. A twofold structure provides a convenient approach through which to explore these issues, fuller details of which are available elsewhere (CLG, 2010e): neighbourhood level community empowerment; and direct involvement with Partnerships.

\section{(i) Neighbourhood level community empowerment}

Areas selected as NDCs in the late 1990s tended to be characterised by high levels of poverty and worklessness, poor health standards, and low educational attainment. In general too, they lacked much in the way of voluntary or community sector infrastructure. The Chief Executive of Manchester NDC pointed out that 'East Manchester was a community that had never really been engaged before, consulted before, even informed...there was a high degree of scepticism, massive degree of anger, frustration and there was little trust' (CLG, 2010c: 34). The challenge of engaging local communities varied depending on factors such as degrees of ethnic and cultural diversity, the stability of local populations, the scale of existing community based organisations, and local regeneration narratives. Within each local context, NDC Partnerships developed strategies to help engender the community dimension. Activities included community audits, resident preference surveys, local and sector fora within which to discuss issues, community based media, small scale funds to support community based initiatives and engender capacity, community workers, and so on. Partnerships consistently sought to engage with, empower and enhance capacity within, their local community. And there are numerous individual-level success stories emerging from local residents engaging with their local Partnership. At first glance, this narrative might thus be seen as a beacon of what the Big Society can achieve.

But digging deeper, the NDC experience actually highlights problems inherent to the entire edifice of 'community'. In part these tensions reflect well-evidenced difficulties which tend to bedevil efforts to engage communities whatever the context (Taylor, 2007). There are too more fundamental questions as to whether attempts to define 'communities of place' are inappropriate in a society where division is driven by interest, occupation, and social stratification. The NDC experience in a sense side-steps that issue because it is what it is: an ABI strongly premised on 'community'.

Nevertheless, there were problems specific to this Programme. For a start, if it is possible to define communities of place, they do not exist at the scale of 10,000 people. There was a consistent message that this was simply too big to make sense to residents (CLG, 2010c). Far from the Programme inevitably instilling a stronger sense of collective purpose, the narrative in some areas was dominated by conflict and tensions, often driven by race. To the Community Regeneration Manager in Newcastle NDC: "there was a quite overt view amongst the community that it was a competition to grab resources for one ethnic community or another' (CLG, 2010c: 38). In at least one instance, Birmingham Aston, the Partnership had to be reconstituted because of institutional paralysis arising from voting patterns largely driven by the ethnicity of board members. There were the usual problems in engaging more 'distanced' groups: the young, older men, some ethnic communities. It was difficult at times too, to manage community expectations: residents assumed an unexpected windfall of $£ 50 \mathrm{~m}$ would lead to massive and immediate changes. And community interest in the Programme anyway tended to diminish. To the Chief Executive at Manchester NDC: 'people move out of the area and get replaced by people who've not engaged before, 
p. 59. Big Society and Community: Lessons from the 1998-2011 New Deal for Communities Programme in England

people fall out with us or each other, decide that they're nor interested any more or that they've got a life after all' (CLG, 2010c: 40).

Underpinning many of these considerations, was a critical dilemma: what was the community dimension and what was it supposed to achieve? This issue is not unique to the NDC Programme. As others reflecting on the regeneration scene have commented '...community involvement is held to be, self-evidently, "a good thing"', it comes as no surprise '...that community involvement generally goes undefined, a mantra interpreted in various ways and leading to a wide range of policies, structures and social processes' (Robinson et al., 2005:15). Definitions of, and policies appropriate to, 'community engagement' were never made clear in the NDC Programme, and as a result Partnerships adopted a catholic range of initiatives designed in some imprecise manner to enhance 'community involvement'.

Perhaps not surprisingly then, there is not a great deal to suggest net positive change in relation to community. Community and social capital indicators improved across the 39 NDC areas in that six year period 2002 to 2008, but then this was true for other deprived areas too. Of eleven indicators of change relating to issues such as trust, neighbourliness and local decision making, just one showed NDC areas seeing statistically more positive change than the comparator areas: people in the area being friendly. For the other ten, positive change in NDC areas was matched by that occurring in these other deprived neighbourhoods. So for instance, trust in the local council rose eight percentage points in NDC areas, but six in comparator areas; trust in local health services six points in both sets of neighbourhoods; residents thinking they could influence local decisions two percentage points in both; and feeling part of the community actually rose one percentage points more in comparator areas (11 percentage points) than in NDC areas. One obvious reason why net positive change was limited was that most residents did not engage much with their local NDC Partnership. In 2008 only about 17 per cent of all residents had been involved in any NDC organised activity in the previous two years (CLG, 2010e). And over 80 per cent of those who had been involved, had played a participative role attending events, and meetings, using services and so on. Very few had been directly involved, say, in helping to run events. This relative lack of direct involvement in NDC activities extended to local elections for community representatives on NDC boards. Between 2006 and 2008 turnouts for elections to NDC boards averaged just 23 per cent (CLG, 2009a). This all has direct relevance to a Big Society agenda within which the community dimension figures prominently. The whole notion of coherent, identifiable, spatially defined, communities is debatable; there is no guarantee that locality based activities will 'bring together' residents; most people in deprived areas do not get involved locally, even within the context of a well funded ABIs: they have other priorities; and as a result it is difficult for locality based initiatives to shift social and community indicators in a positive fashion.

\section{(ii) Direct involvement with Partnerships}

NDC experience allows the community dimension to be cut in a different way by exploring what happens to those who were directly involved with their local Partnership: resident board members (RBMs). In NDC areas, local strategies were overseen by Partnership boards comprising local residents and representatives of relevant service delivery agencies. In 2008 the average size of Partnership Boards was 21, with residents then holding a majority in 26 instances (CLG, 2009b). At some stage in the evolution of the Programme virtually all 39 Boards saw residents in a majority. 
p. 60. Big Society and Community: Lessons from the 1998-2011 New Deal for Communities Programme in England

In 2009 a survey was carried out of more than 300 RBMs who either then were, or who had been, on NDC Boards (CLG, 2010d). There are positive things to say about the experience of this group. There is a general view across key stakeholders that decision making was improved as a result of inputs from RBMs (CLG, 2010c). Residents were, for instance, well placed to comment on the added value of proposals emerging from delivery agencies. In addition RBMs were themselves generally positive about their experiences on boards, their involvement in most decision making activities, and the effect this process had on their lives (CLG, 2010d).

But the most interesting lesson to draw from this direct involvement in NDC activities is that it too, like attempts to engage communities as a whole discussed earlier, raises intriguing lessons and tensions. For a start, RBMs are not reflective of NDC populations as a whole. When compared with all NDC residents, there is an overrepresentation of older, white, employed, more 'middle-class' and better qualified sections of the community. Whilst a predictable finding, this does nevertheless suggest that more deprived localities accommodate fewer people willing, and able to take on key 'community facilitator' roles. Will the areas most needing benefits from the Big Society, be those least able to secure them?

The history of governance within the Programme also contains lessons for the Big Society. The early days of the Programme were characterised by disagreements between RBMs and agency representatives. These were partly driven by a sense on the part of community representatives that delivery agencies, often lumped together into a composite 'local council', had consistently failed to provide an adequate level of service. But often underpinning this frustration was a more principled point. Community representatives might have strong views as to the league table of ills affecting their areas, and ideas as to how these might be addressed. But these understandable assumptions were often simply wrong. There was a consistent overplaying of problems associated with crime, and an equally prevalent underemphasis of more pressing issues, such as say educational attainment levels, and health standards. Equally so, community representatives often sought to address local problems informed by views gleaned from the popular press, rather than from any evidence base. Crime was seen as likely to be moderated through 'more police', rather other approaches rooted, say, in crime prevention measures or restorative justice. Education was too often equated with spending more on local schools, when a more effective policy would have been to focus on parents and children living in NDC areas (CLG, 2010f). Not surprisingly when reflecting on relationships between RBMs and agency professionals, the Chief Executive of Lambeth NDC suggested: 'it might have been good if the partners had been more willing to challenge residents when they are wrong-headed' (CLG, 2010c: 40). It is disingenuous to assume deprived neighbourhoods contain the expertise and capacity accurately to reflect on local needs and sensibly to define solutions to issues.

One local solution which was adopted by some boards was the purchase of physical assets, on the basis that these would provide longer term rental income to sustain investment once NDC funding ceased. This might have been a legitimate approach for NDCs located in economically buoyant areas. Hackney NDC, in London's Shoreditch, adopted this approach in a neighbourhood enjoying rental increases as a result of expanding cultural industries. But for NDCs located in less thriving economies, this was always a riskier strategy. By late 2010 it seemed likely that a legacy property venture funded by Sheffield NDC would cost the local authority, the ultimate accountable body, over $£ 4 \mathrm{~m}$ (Sheffield Telegraph, 2010). This experience is important because one strand of thinking embedded in the Big Society is the assumption that local communities might take on unwanted physical assets. The reality is that most communities do not have the expertise to acquire, manage and successfully sustain 
p. 61. Big Society and Community: Lessons from the 1998-2011 New Deal for Communities Programme in England

physical assets. In line with the views of other observers (Chanan and Miller, 2010; IPPR and PwC, 2010), the NDC experience strongly suggests there is not sufficient capacity within deprived communities for them to 'take over' public services.

However the, ostensibly imaginative, purchase of local assets was atypical of policy making. In practice the active involvement of RBMs tended to dampen down innovation. In the main, RBMs were not aware of more imaginative regeneration schemes adopted elsewhere: they tended to support orthodox interventions. Agencies were happy to go along with that. From their point of view it was better to part-fund known, and trusted, approaches rather than support innovative schemes in NDC neighbourhoods subject to the potentially troublesome involvement of edgy community representatives. However, the Big Society makes the assumption that local strategies, perhaps funded by 'community budgets' (CLG, 2010b), will indeed be adopted to meet specific local needs. It takes a leap of imagination to believe that local authorities and key delivery agencies, which themselves will be going through formidable financial restructuring, are going to be in any position to respond imaginatively to what may be a plethora of disparate, often misguided, frequently ill-informed, local requests. It is a fair assumption that they won't be able, or willing, so to do. There are positive things to say about the experiences of RBMs on the NDC Programme. But this narrative raises important tensions too: the skewed socio-demographic nature of RBMs; strained relationships with delivery agencies; and the tendency towards supporting popularist, unimaginative and often ill-informed solutions to local problems. In various guises these tensions will re-appear in a Big Society agenda driven by 'community'.

\section{A Concluding Comment}

As has been flagged up earlier, the NDC Programme is not a precursor to the Big Society. Nevertheless, there are clear implications for the latter emerging from the experiences of 'community' embedded within the NDC Programme. Based on that NDC narrative the role of the community in the Big Society appears likely to be plagued by problems. Its definition remains unclear. It is unrealistic to imagine that communities can possibly be aware of the nature and depth of local problems. Deprived areas will probably accommodate fewer facilitators of change. And how will delivery agencies respond to what is likely to prove a myriad of ill-conceived ideas when their own resources are being cut? As with many aspects of the Big Society, this focus on community points to an overarching philosophy characterised by ambiguity and lack of clarity. Somewhere in this ill-defined pottage, there are positive, conceivably thoughtprovoking elements. But reflecting on what this powerful NDC evidence base is saying, it is hard to avoid critical comment. Ultimately, the Big Society comes over as a loosely defined, if convenient, slogan adopted by a Conservative Party with previous when it comes to debates about the reality of 'society'. As others have suggested, it is a neat and friendly label to deflect attention from severe cuts in public expenditure (Coote, 2010), and in government contributions to charities and other third arm organisations (Barnard, 2010). It diminishes essential debates focussing on the real problems facing the UK, including accentuating inequalities across society. It avoids one essential element in localist and community driven solutions: the need to allow local authorities greater freedom to levy financial resources (IPPR North, 2010). And it's essentially anti-statist ideology fails to reflect the reality that it was big government which bailed out financial systems in the late 2000s. 
p. 62. Big Society and Community: Lessons from the 1998-2011 New Deal for Communities Programme in England

\section{Notes}

1 Although many of the problems impacting on Scottish and Welsh cities mirror those evident in England, the policy contexts have increasingly diverged; this paper is about English urban policy.

\section{Acknowledgements}

The author would like to thank colleagues in the New Deal for Communities national evaluation team including lan Wilson, Christina Beatty, Mike Foden, Elaine Batty, Sarah Pearson, Peter Tyler, Angela Brennan, Colin Warnock, Geoff Fordham, Charlotte Clarke, Crispian Fuller and Richard Meegan. Thanks are also due to Communities and Local Government and its predecessor departments which funded the 2001-2010 evaluation. The views expressed in this paper are those of the author alone and do not necessarily reflect those of Communities and Local Government.

* Correspondence Address: Paul Lawless, CRESR, Sheffield Hallam University, Unit 10 Science Park, Howard Street, Sheffield, S1 1WB. Email: p.I.lawless@shu.ac.uk.

\section{References}

Alcock, P. (2010) Building the Big Society: anew policy environment for the third sector in England. Voluntary Sector Review 1, 3, 379-89.

Barnard, H. (2010) Big Society: cuts and consequences: a thinkpiece. London: Centre for Charity effectiveness, Cass Business School, City University.

Blond, P. (2010) How the left and right have broken Britain and how we can fix it. London: Faber and Faber.

Cabinet Office (2010a) Modernising Commissioning: increasing the role of charities, social enterprises, mutuals and cooperatives on public service delivery. London: Cabinet Office.

Cabinet Office (2010b) Big Society Programme. London: Cabinet Office. http://www.cabinetoffice.gov.uk/search.aspx?search=big+society+programme

Cameron, D. (2010) Our Big Society Agenda. Speech Liverpool 19/7/10. http://www.conservatives.com/News/Speeches/2010/07/David Cameron Our Big Society Agenda.aspx

Chanan, G. and Miller, C. (2010) The Big Society: how it could work, a positive idea at risk from caricature. PACES.

Clegg, N. (2010) A vision for political reform. Cabinet Office Press release 16/11/10; CAB 202/10. http://www.dpm.cabinetoffice.gov.uk/news/deputy-pm-sets-outvision-political-reform

Communities and Local Government (2006) Strong and prosperous communities: the Local Government White Paper, Cmnd 6939. London: Communities and Local Government.

Communities and Local Government (2009a) Neighbourhood governance: making elections a significant event for partnerships and communities? London: Communities and Local Government.

Communities and Local Government (2009b) The 2008 Partnership Survey: evidence from the New Deal for Communities Programme. London: Communities and Local Government. 
p. 63. Big Society and Community: Lessons from the 1998-2011 New Deal for Communities Programme in England

Communities and Local Government (2010a) The New Deal for Communities experience: a final assessment: The New Deal for Communities national evaluation: Final report Volume 7. London: Communities and Local Government.

Communities and Local Government (2010b) Decentralisation and the Localism Bill: an essential guide. London: Communities and Local Government.

Communities and Local Government (2010c) What works in neighbourhood-level regeneration? The views of key stakeholders in the New Deal for Communities Programme. London: Communities and Local Government, London.

Communities and Local Government (2010d) Running a regeneration programme; the experiences of resident representatives on the boards of New Deal for Communities Partnerships. London: Communities and Local Government.

Communities and Local Government (2010e) Involving local people in regeneration: evidence from the New Deal for Communities Programme: The New Deal for Communities national evaluation: Final report Volume 2. London: Communities and Local Government.

Communities and Local Government (2010f) Narrowing the gap? Analysing the impact of the New Deal for Community Programme on educational attainment. London: Communities and Local Government.

Conservative Party (2010) Big Society, Not Big Government. Conservative Party, London. http://www.conservatives.com/News/News stories/2010/03/ /media LFiles/Downloadable\%20Files/Building-a-Big-Society.ashx

Coote, A. (2010) Cutting it: The 'Big Society' and the new austerity. London: New Economics Foundation.

Dargan, L. (2009) Participation and local urban regeneration: The case of the New Deal for Communities in the UK. Regional Studies, 43, 2, 305-317.

DETR (1998) New Deal for Communities: Phase 1 Proposals: Guidance for Pathfinder Applicants. London: Department of Environment, Transport and the Regions.

DETR (2001) New Deal for Communities Financial Guidance. London: Department of Environment, Transport and the Regions.

Home Office (2005) Together we can, Action Plan. London: Civil Renewal Unit, Home Office.

IPPR and PricewaterhouseCoopers (2010) Capable communities: towards citizenpowered public services. London: IPPR.

IPPR North (2010) Five foundations of real localism. Newcastle: IPPR North.

Kintrea, K. (2007) Policies and programmes for disadvantaged neighbourhoods: recent English experience. Housing Studies, 22, 261-282.

Kisby, B. (2010) The Big Society: power to the people? The Political Quarterly, 81, 4, 484-91.

Neighbourhood Renewal Unit/Office of the Deputy Prime Minister (2005) The New Deal for Communities 2001-2005: An Interim Evaluation: Research Report 17. London: Neighbourhood Renewal Unit/Office of the Deputy Prime Minister.

Oakley, D. and Tsao, H.S. (2006) A new way of revitalizing distressed urban communities? Assessing the impact of the federal Empowerment Zone program. Journal of Urban Affairs, 28, 443-471.

Robinson, F., Shaw, K. and Davidson, G. (2005) On the side of the Angels: community involvement in the governance of neighbourhood renewal. Local Economy, 20, 1, $13-26$

Shaw, K., and Robinson, E. (2010) UK urban regeneration policies in the early twentyfirst century: continuity or change? Town Planning Review, 81, 123-149.

Sheffield Telegraph (2010) Taxpayers face bill of up to $£ 4.5 \mathrm{~m}$ over failed project, 9/12/2010.

Taylor, M. (2007) Community participation in the real world: opportunities and pitfalls in new governance spaces. Urban Studies, 44, 2, 297-317. 
p. 64. Big Society and Community: Lessons from the 1998-2011 New Deal for Communities Programme in England

Van Gent, W.P.C., Musterd, S. and Ostendorf, W. (2009) Disentangling neighbourhood problems: area-based interventions in Western European cities. Urban Research and Practice, 2, 53-67.

Wind-Cowie, M. (2010) Civic Streets: the big society in action, Progressive Conservatism Project. London: Demos. 